\title{
Pengaruh Model Pembelajaran Team Assisted Individualization (TAI) Terhadap Hasil Belajar Siswa pada Mata Pelajaran PPKn Kelas X di MA Al-Intishor Mataram
}

\author{
Komang Sundara', Hasna Usman²
}

\footnotetext{
${ }^{1}$ Pendidikan Pencasila dan Kewarganegaran, Universitas Muhammadiyah Mataram, Email: komangsundara@gmail.com

${ }^{2}$ Pendidikan Pancasila dan Kewarganegaraan, Universitas Muhammadiyah Mataram, Email: hasnausaman34@gmail.com
}

\section{INFO ARTIKEL \\ Riwayat Artikel: \\ Diterima: 20-Februari- \\ 2019 \\ Disetujui: 28-Maret-2019}

\section{Kata Kunci:}

pengaruh

pembeajaran

team assisted

individualization

hasil belajar

\begin{abstract}
ABSTRAK
Abstrak: Model pembelajaran Team Assisted individualization (TAI) merupakan sebuah program pedagogik yang berusaha mengadaptasikan pembelajaran dengan perbedaan individual secara akademik dengan tujuan untuk meminimalisasi pengajaran individual yang terbukti kurang efektif. Tujuan penelitian ini adalah untuk mengetahui apakah model pembelajaran Team Assited Individualization (TAI) dapat mempengaruhi hasil belajar siswa pada PPKn kelas X MA Al-Intishor Mataram tahun pelajaran 2018/2019. Penelitian ini merupakan penelitian kuantitatif dengan pendekatan eksperimen. Desain penelitian yang digunakan Pre-Eksperimen dibagi menjadi tiga macam yaitu: One shot case study, One group pretes-postes, Intact- group comparison. Sampel dalam penelitian ini adalah seluruh siswa kelas X MA Al-Intishor Mataram. Sampel penelitian diambil secara teknik sampling jenuh..Instrumen penelitian yang digunakan dalam penelitian ini adalah pilihan ganda sebanyak 20 soal. Hasil teknik analisis data yang digunakan dalam rumus uji t-paired, maka

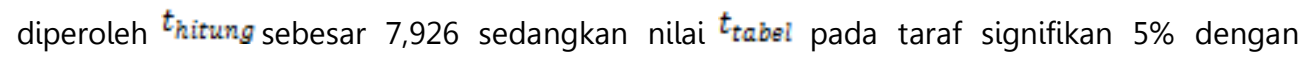
diperoleh harga $t_{\text {tabel }}$ sebesar 1,761. Jadi dari hasil perhitungan dapat di simpulkan $t_{\text {hitung }} \geq t_{\text {tabel }}$. yang berarti hipotesis $(\mathrm{Ha})$ diterima dan hipotesis alternatif $(\mathrm{Ho})$ ditolak sehingga terdapat kemampuan awal siswa, sehingga penelitian ini dapat disimpulkan bahwa ada pengaruh Model Pembelajaran Team Assisted Individualization (TAl) dapat mempengaruhi hasil belajar siswa pada PPKn kelas X MA Al-Intishor Mataram tahun pelajaran 2018/2019.
\end{abstract}

\begin{abstract}
Models of learning Team Assisted Individualization (TAI) is a program that seeks to adapt pedagogic learning with individual differences in academic with the goal to minimize the individual teaching of proven less effective. The purpose of this study was to find out whether the Team Assisted Individualization (TAI) learning model can affect student learning outcomes in class X MA of Al-Intishor Mataram academic year 2018/2019. This research is quantitative research with an experimental approach. The research design was used pre-launch Experiments are divided into three kinds, namely: One-shot case study, One group presses-posts, Intact-group comparison. The sample in this study is the whole grade $X$ MA Al-Intishor Mataram. Research samples were taken in sampling saturated. .. The research instrument used in this study was a double choice of as many as 20 items. The results of data analysis techniques used in the t-test paired formula then acquired for 7.926 while values in the $5 \%$ significant level with obtained a price of 1.761 . So from the calculation result can be concluded. that means the hypothesis ( $\mathrm{Ha}$ ) received and the alternative hypothesis $(\mathrm{Ho})$ was rejected so there is the ability of the students, so this research it can be concluded that there is an influence of Model Learning Team Assisted Individualization (TAI) can affect the learning outcomes of students in class X PPKn MA Al-Intishor Mataram 2018/2019 lessons year.
\end{abstract}

\section{A. LATAR BELAKANG}

Pendidikan adalah ilmu yang membicarakan masalah-masalah pendidikan secara umum, menyeluru, dan abstrak, disamping praktik penggunaannya[1]. Pendidikan memiliki peran yang sangat penting dalam upaya meningkatkan sumber daya manusia ke arah yang lebih baik. Pendidikan diharapkan mampu membentuk peserta didik yang dapat mengembangkan sikap, keterampilan dan kecerdasan intelektualnnya agar menjadi manusia yang terampil, cerdas, serta berakhlak mulia.

Seperti yang tercantum dala Sistem Pendidikan Nasional menyebutkan Bab II pasal 3, menyatakan bahwa: Pendidikan Nasional berfungsi mengembangkan kemampuan dan membentuk watak serta peradaban bangsa yang bermartabat dalam rangka mencerdaskan kehidupan bangsa, bertujuan untuk berkembangnya 
potensi peserta didik agar menjadi manusia yang beriman dan bertaqwa kepada Tuhan Yang Maha Esa, berakhlak mulia, sehat, berilmu, cakap, kreatif, mandiri, dan menjadi warga Negara yang demokratis serta bertanggung jawab[2]. Pendidikan merupakan investasi jangka panjang yang memerlukan usaha dan dana yang cukup besar, hal ini diakui oleh semua orang atau suatu bangsa demi kelangsungan masa depannya. Demikian halnya dengan Indonesia menaruh harapan besar terhadap pendidikan dalam kehidupan.

Seperti yang tertera pada Pasal 1 ayat yaitu: guru adalah Pendidik profesional dengan tugas utama mendidik, mengajar, membimbing, mengarahkan, melatih, menilai, dan mengevaluasi peserta didik pada pendidikan anak usia dini jalur pendidikan formal, pendidikan dasar, dan pendidikan menengah[3].

Berdasarkan pengertian di atas dapat disimpulkan bahwa, dalam proses pembelajaran yang paling berpengaruh adalah adanya guru dan siswa. Di mana guru berperan penting untuk mendidik dan memberikan pengetahuan yang dimilikinya. Guru harus bisa menyesuaikan model pembelajaran agar peserta didik dapat mencapai hasil yang maksimal.

Adapun kualitas pendidikan di Indonesia menurut Soedjarto dalam skripsi Anjani bahwa rendahnya mutu atau kualitas pendidikan disebabkan oleh karena pemberian peranan yang kurang proporsional terhadap sekolah, kurang memadainya perencanaan, pelaksanaan, dan pengolahan sistem kurikulum, dan penggunaan prestasi hasil belajar secara kognitif sebagai satu kesatuannya indikator keberhasilan pendidikan, juga disebabkan karena sistem evaluasi tidak secara berencana didudukan sebagai alat pendidikan dan bagian terpadu dari sistem kurikulum[4].

Pengembangan kurikulum merupakan proses yang kompleks yang melibatkan beberapa komponen yang saling terkait terutama proses pembelajaran di kelas sehingga saat ini masih juga ditemukan pengajar yang memposisikan siswa sebagai objek belajar, bukan sebagai individu yang harus dikembangkan potensi yang dimilikinya. Kurikulum memegang peranan yang sangat penting. Menurut [5] kurikulum bersifat dinamis serta harus selalu dilakukan perubahan dan pengembangan agar dapat mengikuti perkembangan dan tuntutan zaman.

Dari uraian di atas maka dapat disimpulkan bahwa kurikulum harus selalu dilakukan perubahan dan selalu ada perkembangan agar dapat mengikuti perkembangan zaman. Maka dari itu perlu adanya penyempurnaan Kurikulum dari KTSP ke Kurikulum 2013 (Kurtilas), yang pada saat ini difokuskan pada pembentukan kompetensi dan karakter peserta didik, berupa gabungan dari pengetahuan,keterampilan, dan sikap yang dapat didemonstrasikan peserta didik,karena itu guru haruspaham terhadap konsep yang dipelajarinya[5]
Kurikulum 2013 dalam pembentukan kompetensi dan karakter peserta didik memiliki beberapa keunggulan yaitu 1) Kurikulum 2013 menggunakan pendekatan yang bersifat alamiah (konseptual), karena berangkat, berfokus, dan bermuara pada hakekat peserta didik untuk mengembangkan berbagai kompetensi sesuai dengan potensinya masing-masing. 2) Kurikulum 2013 berbasis karakter dan kompetensi boleh jadi mendasari pengembangan kemampuan-kemampuan lain. 3) Ada bidang studi atau mata pelajaran tertentu yang dalam pengembangannya lebih tepat menggunakan pendekatan kompetensi, terutama yang berkaitan dengan keterampilan[5].

Sejalan dengan perubahan tersebut, maka guru harus dapat menemukan model pembelajaran baru yang dapat memberikan semangat bagi siswa, oleh karena itu guru harus dapat membuat suatu pengajaran menjadi lebih efektif juga menarik sehingga bahan pelajaran yang disampaikan akan membuat siswa merasa senang dan merasa perlu untuk mempelajari bahan pelajar tersebut.

Untuk mengatasi permasalah di atas dan guna untuk mencapai tujuan pendidikan secara maksimal, peran guru sangat penting dan diharapkan guru memiliki cara atau model mengajar yang baik dan mampu memilih model pembelajaran yang tepat dan sesuai dengan konsep-konsep kurikulum 2013. Untuk itu diperlukan suatu upaya dalam rangka meningkatkan mutu pendidikan dan pengajaran salah satunya adalah dengan memilih strategi atau cara dalam menyampaikan materi pelajaran agar diperoleh peningkatan hasil belajar siswa. Misalnya dengan membimbing siswa untuk bersamasama terlibat aktif dalam proses pembelajaran, dan mampu membantu siswa berkembang sesuai dengan taraf intelektualnya akan lebih menguatkan pemahaman siswa terhadap konsep-konsep yang diajarkan. Pemahaman ini memerlukan minat dan rasa ingin tahu, tanpa adanya minat menandakan bahwa siswa tidak mempunyai rasa ingin tahu dalamkegiatan belajar. Untuk itu, guru harus memberikan suntikan dalam bentuk rasa ingin tahu sehingga dengan bantuan itu peserta didik dapat keluar dari kesulitan belajar.

Berdasarkan hasil observasi awal melalui dokumentasi hasil ujian semester data presentasi ketuntasan siswa pada mata pelajaran PPKn kelas X MA Al-Intishor Mataram ditemukan permasalahan dalam proses belajar antara lain: (1) rendahnya rangsangan siswa dalam menjawab pertanyaan yang dilontarkan guru, (2) kurangnya pertanyaan yang diajukan oleh siswa, dan (3)rendahnya hasil belajar siswa pada tahun pelajaran 2017/2018. Rendahnya hasil belajar tersebut disebabkan oleh guru yang kurang melibatkan siswa dalam kegiatan pembelajaran, rendahnya minat siswa untuk terlibat dalam pemecahan masalah, kurangnya pemahaman siswa terhadap materi, siswa kurang bertanggung jawab dalam menyelesaikan tugas yang diberikan guru. Selain itu guru masih menggunakan 
model konvensional, dimana guru sebagai sumber informasi (teacher center learning) dalam proses pembelajaran di kelas.

Hasil belajar siswa juga dilihat dari perubahan tingkah laku yang terjadi pada diri siswa setelah melakukan kegiatan pembelajaran. Hal ini menuntut guru untuk lebih kreatif dalam menerapkan model pembelajaran yang tepat dalam proses pembelajaran, salah satu yang akan diterapkan adalah Model Pembelajaran Team Assisted individualization (TAI).

Model pembelajaran Team Assisted individualization (TAI) merupakan sebuah program pedagogik yang berusaha mengadaptasikan pembelajaran dengan perbedaan individual secara akademik dengan tujuan untuk meminimalisasi pengajaran individual yang terbukti kurang efektif, selain juga ditujukan untuk meningkatkan pe-ngetahuan, kemampuan, serta motivasi siswa dengan belajar kelompok[6]. Model pembelajaran ini sangat mengasah siswa untuk bekerja sama dan bertukar pikiran dengan temannya sehingga siswa yang sebelumnya kurang mengerti menjadi lebih mengerti mengenai materi yang diajarkan.

Adapun manfaat model pembelajaran Team Assisted Individualization (TAI) seperti yang dikatakan Slavin dalam [6] bahwa: (1) me-minimalisasi keterlibatan guru dalam pemeriksaan dan pengelolaan rutin; (2) melibatkan guru untuk mengajar kelompok-kelompok kecil yang heterogen; (3) memudahkan siswa untuk melaksanakannya karena teknik operasional yang cukup sederhana; (4) memotivasi siswa untuk mempelajari materi-materi yang diberikan secara cepat dan akurat, tanpa jalan pintas; (5) memungkinkan siswa untuk bekerja sama dengan siswa-siswa lain yang berbeda sehingga tercipta sikap positif diantara mereka.

Berdasarkan uraian latar belakang diatas, maka tujuan yang ingin dicapai dalam penelitian ini adalah untuk mengetahui pengaruh metode pembelajaran Team Assisted Individualization (TAI) terhadap hasil belajar siswa pada mata pelajaran PPKn kelas X MA Al-Intishor.

\section{B. METODE PENELITIAN}

\section{Rancangan Penelitian}

Penelitian ini adalah penelitian eksperimen, eksperimen dapat diartikan sebagai metode pe-nelitian yang bertujuan untuk mencarii pengaruh perlakuan tertentu terhadap yang lain dalam kondisi yang terkendalikan [7]. Menurut [8] sifat atau ciri-ciri eksperimen adalah pengendalian atau kontrol, manipulasi atau perlakuan, dan pengamatan atau pengukuran.

Peneliti menggunakan One Group Presest-Posttest. Pada desain ini terdapat pretest, sebelum diberi perlakuan. Dengan demikian hasil perlakuan dapat diketahui lebih akurat, karena dapat membandingkan dengan keadaan sebelum diberikan perlakan[7].
Peneliti menggunakan jenis penelitian ini karena mengandung paradigma bahwa terdapat suatu kelompok diberi treatment atau perlakuan dan selanjutnya diobservasi hasilnya, akan tetapi sebelum diberi perlakuan terdapat pretes untuk mengetahui kondisi awal. Dengan demikian, hasil perlakuan dapat lebih akurat karena dapat membandingkan dengan keadaan sebelum diberi perlakuan.Adapun desain penelitian ini yaitu sebagai berikut:

Tabel Desain One group Pretest-postest

$\begin{array}{lll}\text { Pre-test } & \text { Perlakuan } & \text { Post-test } \\ \text { Y1 } & \mathrm{X} & \text { Y2 }\end{array}$

Keterangan:

$\mathrm{X}=$ Perlakuan yang diberikan

Y1 = Nilai/skor pre-test sebelum perlakuan

Y2 = Nilai/skor post-test setelah diberikan perlakuan

\section{Populasi dan Sampel Penelitian}

\section{a) Populasi Penelitian}

Populasi adalah wilayah generalisasi yang terdiri atas obyek/subyek yang mempunyai kualitas dan karateristik tertentu yang ditetapkan oleh peneliti untuk dipelajari dan kemudian ditarik kesimpulannya[7]. Populasi adalah terdiri dari subyek/obyek yang mempunyai kualitas dan karateristik tertentu yang ditetapkan oleh peneliti[8].

Berdasarkan pendapat diatas, maka yang menjadi populasi dalam penelitian ini adalah siswa kelas X MA Al-Intishor Tahun pelajaran 2018/2019.

\section{b) Sampel Penelitian}

Sampel adalah bagian dari jumlah dan karakteristik yang dimiliki atau oleh populasi tersebut[9]. Sampel adalah sebagian dari populasi [10].

Penelitian ini menggunakan teknik sampling jenuh. Sampling jenuh adalah teknik penentuan sampel bila semua anggota populasi digunakan sebagai sampel. Hal ini sering dilakukan bila jumlah populasi relatif kecil kurang dari 30 orang[7]. Dalam penelitian ini yang menjadi sampel penelitian adalah siswa kelas X MA AlIntishor Mataram sebanyak 16 orang.

\section{Teknik Pengumpulan Data}

secara umum, teknik pengumpulan data yang dapat dan lazim digunakan dalam penelitian adalah observasi, wawancara, angket, skala, dokumentasi, dan tes. Dalam penelitian ini, peneliti menggunakan 3 teknik dalam mengumpulkan data yaitu tes dan dokumentasi, observasi. [11]

\section{a) Test}

Menurut Sudijono dalam [12] Tes adalah alat ukur atau prosedur yang digunakan dalam rangka pengukuran dan penilaian. Menurut [1] tes merupakan instrumen alat ukur untuk mengumpulkan data di mana dalam memberikan respons atau pertanyaan dalam instrumen, peserta didorong untuk menunjukan penampilan maksimalnya. 
Tes dalam penelitian ini adalah menggunakan tes obyektif yang diberikan kepada semua siswa kelas X MA Al-Intishor untuk mengukur hasil belajar, khususnya aspek pengetahuan. Adapun pengertian tes obyektif adalah tes yang keseluruhan informasi yang diperlukan untuk menjawab tes telah tersedia[1]. Metode tes yang digunakan dalam penelitian ini adalah tes obyektif bentuk pilihan ganda. Tes tersebut berupa pre-test yang diberikan kepada siswa sebelum melakukan perlakuan dan post-test sesudah perlakuan dengan tujuan untuk memperoleh data hasil belajar siswa mata pelajaran PPKn.

\section{b) Dokumentasi}

Dokumentasi adalah catatan peristiwa yang sudah berlalu[7]. Dokumentasi adalah teknik pengumpulan data yang tidak langsung ditujukan kepada subjek penelitian tetapi melalui dokumen [11].

Dalam penelitian ini metode dokumentasi digunakan untuk memperoleh data-data sekolah berupa data keadaan siswa, data keadaan guru dan pegawai sekolah dan sarana dan prasarana sekolah.

\section{c) Observasi}

Observasi dilakukan untuk menemukan data dan informasi dari gejala atau fenomena (kejadian atau peristiwa) secara sistematis dan didasarkan pada tujuan penyelidikan yang telah dirumuskan [11].

Observasi dilakukan oleh peneliti berupa observasi sikap social dengan cara pengamatan dan pencatatan mengenai pelaksanaan pembelajaran di kelas. Lembar instrumen observasi siswa dengan menggunakan model pembelajaran Team Assisted Individualization (TAI) ini bertujuan untuk mengukur aktivitas siswa selama proses pembelajaran.

\section{Indentifikasi dan Definisi Operasional Variabel}

\section{a) Identifikasi Variabel}

Variabel adalah suatu sifat atau nilai dari orang, Subjek atau kegiatan yang mempunyai variasi tertentu yang ditetapkan oleh peneliti[8]. Variabel penelitian pada dasarnya adalah segala sesuatu yang berbentuk apa saja yang ditetapkan oleh peneliti untuk dipelajari sehingga diperoleh informasi tentang hal tersebut, kemudian ditarik kesimpulannya[7].

Dalam penelitian ini yang menjadi variabel independen atau variabel $\mathrm{X}$ adalah model pembelajaran Team Assisted Individualization (TAI) sedangkan yang menjadi variabel dependen atau variabel $\mathrm{Y}$ adalah hasil belajar PPKn siswa kelas X MA Al-Intishor Mataram.

\section{b) Definisi Operasional Variabel}

Definisi operasional variabel adalah defenisi yang diberikan kepada satu variabel dengan cara melihat pada dimensi tingkah laku atau properti yang ditujukan oleh konsep dan mengkategorikan hal tersebut menjadi elemen yang dapat diukur dan diamati[13]. Definisi operasional variable adalah definisi yang didasarkan atas sifat-sifat hal yang didefinisikan yang dapat diamati (diobservasi) sehingga apa yang dilakukan oleh peneliti terbuka untuk diuji kembali oleh orang lain. [14]

Variabel yang digunakan dalam penelitian ini adalah Model pembelajaran TAI sebagai variabel Xdan hasil belajar PPKn sebagai variabel Y. Adapun definisi dari masing-masing variabel adalah sebagai berikut:

$\begin{array}{ccc}\text { 1) Model Pembelajaran } & \text { Team } & \text { Assisted } \\ \text { Individualization (TAI) } & & \\ \text { Model pembelajaran } & \text { Team } & \text { Assisted }\end{array}$
Individualization (TAI) dilakukan dengan dibentuknya kelompok-kelompok kecil dalam satu kelas yang terdiri dari 4-5 siswa dalam tiap kelompoknya dengan kemampuan heterogen dan diikuti pemberian bantuan individu bagi siswa yang memerlukan. Menurut [15] model pembelajaran TAI merupakan suatu usaha untuk mendesain suatu bentuk pengajaran individu yang akan memecahkan masalah pembelajaran individu yang tidak efektif, dengan meminta siswa belajar bersama dalam kelompok. Dalam hal ini diterapkan bimbingan antar teman yaitu siswa yang pandai bertanggung jawab terhadap siswa yang kurang pandai, disamping itu dapat meningkatkan partisipasi siswa dalam kelompok kecil. Indikator pada variabel ini yaitu hasil tes formatif mata pelajaran PPKn setelah menggunakan model pembelajaran TAI, pengukuran variabel yaitu tingkat besarnya hasil tes formatif mata pelajaran PPKn setelah menggunakan model pembelajaran TAI, serta skala pengukuran yaitu skalah interval. Instrumen pembelajaran terdiri atas silabus, RPP, model pembelajaran.

\section{2) Hasil Belajar PPKn}

Hasil belajar adalah kemampuan-kemampuan yang dimiliki siswa setelah menerima pengalaman belajarnya. Hasil belajar dalam penelitian ini menggunakan hasil belajar secara sikap berupa hasil observasi, keterampilan berupa hasil tes praktik, dan keterampilan berupa hasil tes pilihan ganda.

Pengukuran hasil belajar dalam penelitian menggunakan tes berupa tes pilihan ganda.Tes pilihan ganda terdiri atas suatu pemberitahuan tentang pengertian yang belum lengkap dan untuk melengkapinya harus memilih salah satu dari beberapa kemungkinan jawaban yang telah disediakan. Pengukuran hasil belajar siswa diperoleh dengan memberikan tes materi tentang Hak Asasi Manusia (HAM) pada kelas X. Tes dilakukan sebanyak dua kali yaitu berupa pre-test dan post-test. Tujuan pre-test yaitu untuk mengetahui hasil kemampuan awal siswa sebelum diberi perlakuan dan tujuan dari pos-test yaitu untuk mengetahui kemampuan siswa setelah diberi perlakuan. Peningkatan hasil belajar diketahui dari skor pre-test dan pos-tes. Pengukuran hasil belajar yang digunakan adalah skala interval dengan tipe skala gutmen.

\section{Instrumen Penelitian}


Instrumen penelitian adalah alat ukur yang digunakan untuk mengukur dalam rangka pengumpulan data[16]. Penelitian kuantitatif, kualitas instrumen penelitian berkenaan dengan validitas dan reliabilitas instrumen dan kualitas pengumpulan data berkenaan ketepatan cara-cara yang digunakan untuk mengumpulkan data. [7]

Dalam penelitian ini, peneliti menggunakan tes pilihan ganda. Pilihan ganda (multiple chois), terdiri atas suatu pertanyaan atau keterangan tentang suatu pengertian yang belum lengkap, dan untuk melengkapinya harus memilih terdiri satu terdiri atas bagian keterangan dan bagian kemungkinan jawaban atau alternatif. Kemungkinan jawaban terdiri atas satu jawaban yang benar (sebagai kunci jawaban) dan beberapa pengecoh (distractor)[17].

Tes ini dibuat untuk mengetahui kemampuan siswa dalam memahami materi yang telah diajarkan. Dari uraian diatas, instrumen penelitian dalam penelitian ini berupa tes pilihan ganda pre-test dan post-test.

\section{a. Hasil Uji Validitas}

Instrumen yang digunakan dalam Suatu harus valid. Valid berarti instrumen tersebut dapat digunakan untuk mengukur apa yang seharusnya diukur[7]. Menurut [12] validitas adalah suatu konsep yang berkaitan dengan sejauh mana tes telah mengukur apa yang seharusnya diukur.

Dari pendapat diatas dapat disimpulkan bahwa validitas adalah suatu ukuran yang menunjukan kevalidan atau kesahihan suatu instrumen. Bentuk instrumen tes yang dibuat yaitu objektif tes maka pola pengujian yang digunakan adalah mengkolerasi skor item kepada skor total item, dan berlaku untuk seluruh item tes. Adapun formula korelasi yang digunakan adalah kolerasi poin biserial. Adapun rumusnya sebagai berikut:

$$
\mathrm{Y}_{\mathrm{pbi}}=\frac{\mathrm{Mp}-\mathrm{M} 1}{\mathrm{St}} \sqrt{\frac{\mathrm{p}}{\mathrm{q}}}
$$

Keterangan:

$\mathrm{Y}_{\mathrm{pbi}}=$ Koefisien korelasi biserial

$\mathrm{M}_{\mathrm{p}}=$ Rerata skor dari subjek yang menjawab betul

$\mathrm{M}_{\mathrm{t}}=$ Rerata skor dari subjek yang menjawab salah

$\mathrm{S}_{\mathrm{t}} \quad=$ Standar deviasi dari skor total proporsi

$\mathrm{P} \quad=$ proporsi siswa yang menjawab benar ( $\mathrm{p}^{\text {banyaknya siswa yang benar }}$ )

$\mathrm{q}=$ proporsi siswa yang menjawab salah $(\mathrm{q}=1-p)$

Jumlah butir soal yang peneliti buat untuk mendapatkan data tentang hasil belajar siswa adalah 25 butir dengan 4 pilihan (Option) jawaban untuk masingmasing butir soal. Instrument tes sebelum peneliti sebarkan kepada siswa terlebih dahulu dilaksanakan pengujian pada bulan Juli 2018 di kelas X MA Al-
Intishor Mataram yang berjumlah 16 orang. Suatu butir item pertanyaan dikatakan valid jika nilai koefisien korelasi antara $\mathrm{r}$ hitung lebih besar dari $\mathrm{r}$ tabel ( $\mathrm{r}$ hitung $\geq r$ tabel) dan dikatakan tidak valid ketika nilai $r$ hitung lebih kecil dari $r$ tabel ( $r$ hitung $\leq \mathrm{r}$ tabel). Untuk uji coba tes item pertama dengan jumlah responden atau $\mathrm{n}=16$ pada taraf kesalahan $5 \%$ dengan nilai rtabel $=$ 0,497 dan rhitung $=3,221$. Dari hasil perhitungan validitas butir soal tersebut menunjukkan nilai $r$ hitung lebih besar dari nilai $r$ tabel. Ini menunjukkan bahwa dari 25 soal yang diujikan terdapat 20 soal yang valid dan 5 soal yang tidak valid.

\section{b. Uji Reliabilitas}

Menurut Thorndike dan Hagen dalam [1] reliabilitas berhubungan dengan akurasi instrumen dalam mengukur apa yang diukur, kecermatan hasil ukur dan seberapa akurat seandainya dilakukan pengukuran ulang. Menurut [12] Realibilitas yang berasal dari kata reliability berarti sejauh mana hasil suatu pengukuran dapat dipercaya.

Dari pendapat diatas dapat disimpulkan bahwa reliabilitas adalah kosistensi suatu tes untuk mengukur atau mengamati sesuatu yang menjadi objek ukur. Dalam uji reabilitas berupa tes digunakan Keder Richarson 20 (KR-20). Adapun rumus KR-2O sebagai berikut:

$$
\mathrm{r}_{11}=\left(\frac{n}{n-1}\right)\left(\frac{s 2-\Sigma p q}{s 2}\right)
$$

\section{Keterangan:}

r11 $=$ reliabilitas tes secara keseluruhan

$\mathrm{n}=$ Banyaknya item

S2 = standar deviasi dari tes (standar deviasi adalah akar varians

$\mathrm{P}$ = proporsi subjek yang menjawab benar

$\mathrm{Q}=$ proporsi subjek yang menjawab salah $(\mathrm{q}=1-\mathrm{p})$

$\Sigma p q=$ Jumlah hasil perkalian antar $\mathrm{p}$ dan $\mathrm{q}$

Alasan penggunaan rumus KR-20 dalam reabilitas adalah jika $r_{\text {hitung }}>r_{\text {tabel }}$ maka item instrumen dapat dikatakan reliabel atau konsisten, sebaliknya jika nilai $r_{\text {hitung }}<r_{\text {tabel }}$ maka item-item instrumennya dinyatakan tidak reliabel.

Diketahui:

$$
\begin{aligned}
& \mathrm{N}: 16 \quad \mathrm{~S}^{2}: 21,15135929 \quad \sum \mathrm{pq}: 2,98 \\
& \begin{array}{r}
\mathrm{S}^{2}=\frac{\sum \mathrm{x}^{2}-\frac{\left(\sum \mathrm{x}\right)^{2}}{\mathrm{~N}}}{N}=\frac{7496-\frac{(888)^{2}}{16}}{16}= \\
=\frac{7496-\frac{114244}{16}}{16}=\frac{7496-71402}{16}=\frac{7488,8}{16}=468,06 \\
\mathrm{R} 11=\left(\frac{n}{n-1}\right)\left(\frac{s_{2}-\sum p q}{s_{2}}\right)=\left(\frac{16}{16-1}\right)\left(\frac{468,06-2,98}{468,06}\right) \\
=\left(\frac{16}{15}\right)\left(\frac{465,08}{468,06}\right)=(1,07)(0,99)=1,06
\end{array}
\end{aligned}
$$


Hasil uji reabilitas dimana soal yang diuji validitas dari ke 25 soal, dan hanya 20 yang valid yaitu nomor soal $1,2,3,4,5,6,7,8,9,10,11,12,13,14,15,16,17,18$, $19,20,21,22,23,24,25$, sehingga dalam perhitungan uji reabilitas yang valid saja dihitung, dan yang tidak valid tidak ikut disertakan dalam perhitungan uji reabilitas yaitu nomor soal $1,3,4,5,7,8,9,11,12,13,14,15,17,18$, 20, 21, 22, 24, 25, dengan demikian hasil dari perhitungan uji reabilitas menggunakan rumus Richardson 20 (KR-20) dengan membandingkan $r_{\text {hitung }}=1,06$ sedangkan $r_{\text {tabel }}=0,497$ dengan demikian maka soal instrumen dapat disimpulkan realibel, karena $r_{\text {hitung }}>r_{\text {tabel }}$.

\section{Teknik Analisis Data}

Analisis data adalah kegiatan setelah data dari seluruh responden atau sumber data lain terkumpul. Kegiatan dalam analisis data adalah mengelompokan data berdasarkan variabel dan jenis responden, mentabulasi data berdasarkan variabel dari seluruh responden, menyajikan data tiap variabel yang diteliti, melakukan perhitungan untuk menjawab rumusan masalah, dan melakukan perhitungan untuk menguji hipotesis yang telah diajukan[7].

\section{a. Uji Prasyarat analisis}

Sebelum dilakukan pengujian hipotesis maka terlebih dahulu dilakukan uji prasyarat analisis berupa uji normalitas dan homogenitas untuk mengetahui apakah varian kedua sampel tersebut homogen atau tidak.

\section{1) Uji Normalitas}

Dalam penelitian ini pengujian normalitas menggunakan rumus Chi-kuadrat. Adapun rumus ChiKuadrat adalah sebagai berikut:

$$
\begin{aligned}
& \mathrm{X}^{2}=\sum_{i=i}^{n} \frac{(f \circ-f e)^{2}}{f e} \\
& \text { Sugiyono (2017) } \\
& \text { Keterangan: } \\
& \mathrm{X} 2 \quad=\text { Chi-Kuadrat } \\
& \mathrm{Fo} \quad=\text { Frekuensi yang observasi } \\
& \mathrm{Fe}=\text { Frekuensi yang diharapkan } \\
& \text { 2) Homogenitas }
\end{aligned}
$$

Data yang diperoleh terlebih dahulu dianalisis dengan uji $\mathrm{F}$ untuk mengetahui homogenan varians. Menurut [7] pengujian homogenitas varians digunakan uji $\mathrm{F}$ dengan rumus:

$$
\mathrm{F}=\frac{\text { varians terbesar }}{\text { varians terkecil }}
$$

\section{b. Uji Hipotesis}

Uji hipotesis bertujuan untuk mengetahui tingkat kemampuan siswa. Hasil yang diharapkan dari uji hipotesis ini adalah adanya kemampuan siswa sesudah diberikan perlakuan. Analisis data yang digunakan dalam penelitian ini adalah t-tes atau bisa disebut dengan uji-t. Menurut [7] bila sampel berkolerasi/berpasangan, misalnya mem-bandingkan sebelum dan sesudah treatmen atau perlakuan, atau membandingkan hasil dari Pret test dan Post test maka digunakan t-tes sampel. Dalam melakukan uji t-test syaratnya data harus homogen dan normal.

Rumus yang digunakan adalah sampel berpasangan/paired sampel t-test, rumus tersebut digunakan untuk membandingkan rata-rata dua group sampel berpasangan. Sampel berpasangan diartikan sebagai sebuah sampel dengan subjek yang sama namun mengalami 2 perlakuan yang berbeda yaitu perlakuansebelum dan sesudah dilakukan treatmen. Rumus paired t-testsebagai berikut:

$$
t=\frac{\bar{X}_{1}-\bar{X}_{2}}{\sqrt{\frac{S_{1}^{2}}{n_{1}}}+\frac{S_{2}^{2}}{n_{2}}-2 r\left(\frac{S_{1}}{\sqrt{n_{1}}}\right)\left(\frac{S_{2}}{\sqrt{n_{2}}}\right)}
$$

$$
\begin{aligned}
& \text { (Sugiyono, 2017:274) } \\
& \text { Keterangan: } \\
& \bar{X}_{=} \text {Nilai rata-rata sampel } 1 \\
& \overline{\mathrm{X}}_{=}=\text {Nilai rata-ratasampel } 2 \\
& \mathrm{~S}_{1}^{2}=\text { Varians sampel } 1 \\
& S_{2}^{2}=\text { Varians sampel } 2 \\
& \mathrm{r}=\text { Korelasi antara dua sampel } \\
& S_{1}=\text { simpangan baku sampel } 1 \\
& S_{2}=\text { simpangan baku sampel } 2
\end{aligned}
$$

\section{HASIL DAN PEMBAHASAN}

\section{Deskripsi Data}

1) Deskripsi Data Pret Test

Deskripsi data hasil belajar siswa pret test dengan menggunakan model pembelajaran ceramah.

Tabel 1

Hasil pree test siswa

\begin{tabular}{cll}
\hline No. & Nama siswa & $\mathrm{X}_{1}$ \\
\hline 1. & Ahmad Yusuf Az Zuhri & 40 \\
2. & Aswandi & 50 \\
3. & Dwi Nur Astuti & 70 \\
4. & Hasbiyallah & 55 \\
5. & Heriawan & 35 \\
6. & Hilwan & 60 \\
7. & Hirman & 45 \\
8. & Husul Khatimah & 50 \\
9. & Iqozul Human & 35 \\
10. & Liza Amelia & 45 \\
11. & Miftahul Waruf & 45 \\
12. & Nasarudin & 60 \\
13. & Rahmi & 55 \\
14. & Samsul Hadi & 70 \\
15. & Sudirja & 40 \\
16. & susilawati & 45 \\
\hline
\end{tabular}




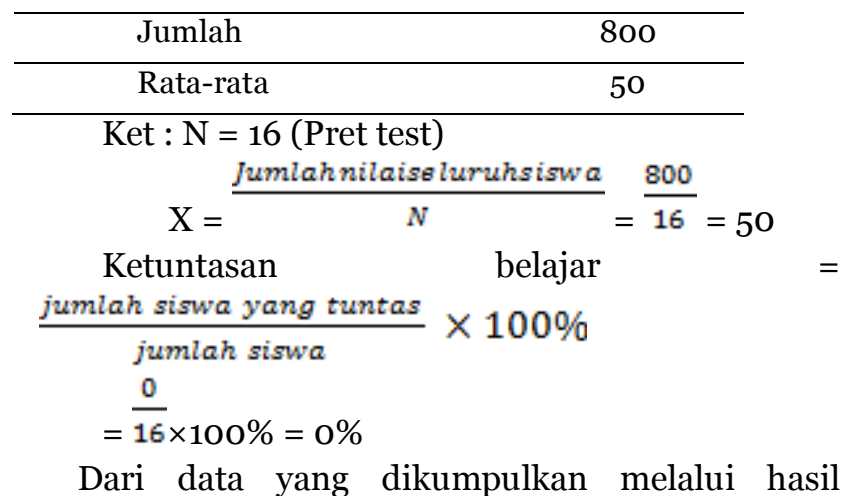
belajardengan jumlah siswa 16 orang,nilai rata-rata 50, dan kecenderungan data Pret testadalah o\% termasuk dalam pengkategorian gagalo\%-33\%) karena tidak ada siswa yang memperoleh nilai di atas kriteria ketuntasan minimal (KKM) yaitu 75 .

2) Deskripsi Data Post Test

Tabel 2

Hasil post test Siswa

\begin{tabular}{lll}
\hline No. & Nama siswa & X2 \\
\hline 1. & Ahmad Yusuf Az Zuhri & 95 \\
2. & Aswandi & 85 \\
3. & Dwi Nur Astuti & 60 \\
4. & Hasbiyallah & 70 \\
5. & Heriawan & 75 \\
6. & Hilwan & 80 \\
7. & Hirman & 70 \\
8. & Husul Khatimah & 85 \\
9. & Iqozul Human & 65 \\
10. & Liza Amelia & 75 \\
11. & Miftahul Waruf & 75 \\
12. & Nasarudin & 80 \\
13. & Rahmi & 85 \\
14. & Samsul Hadi & 90 \\
15. & Sudirja & 85 \\
16. & susilawati & 80 \\
\hline & $\quad$ Jumlah & 1255 \\
& $\quad$ Rata-rata & 78,44
\end{tabular}

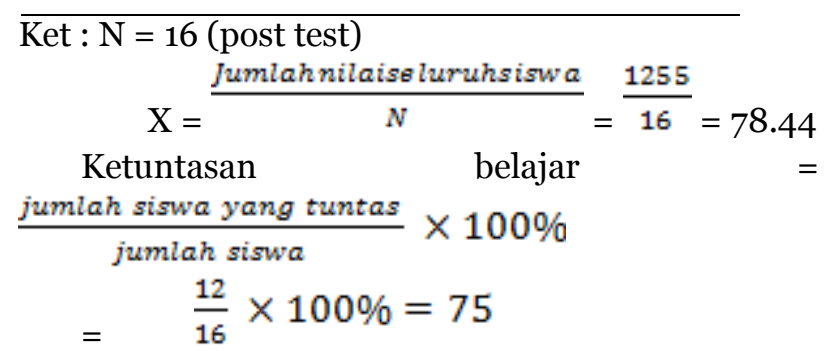

Dari data yang dikumpulkan melalui hasil belajar mengunakan model pembelajaran TAI dengan jumlah siswa 16 orang, dimana nilai rata-rata post test adalah 78,44 , dengan kecenderungan data posttest adalah $75 \%$ termasuk dalam pengkategorian baik (68\%-85\%).

2. Uji Prasayarat Analisis

a. Uji Normalitas

Sebelum melakukan uji hipotesis terlebih dahulu dilakukan uji normalitas. uji normalitas hasil belajar dilakukan dengan cara membandingkan jumlah xhitung dengan Xtabel pada taraf sinifikan. Pret test dan post test dilakukan uji coba normalitas, Untuk mengetahui distribusi hasil yang diperoleh. Berikut ini disajikan uji normalitas yang dilakukan pada masing-masing data.

Tabel 3

Uji Normalitas Data Pret test dan Post test

\begin{tabular}{clccl}
\hline Sampel & $\begin{array}{l}\text { X2 } \\
\text { hitung }\end{array}$ & X2 tabel & Dk & Keterangan \\
\hline Pret test & 2,352 & 11,070 & 6 & Normal \\
Posttest & 1,247 & & 6 & Normal \\
\hline
\end{tabular}

\section{b. Uji Homogenitas}

Uji homogenitas dilakukan untuk mengetahui apakah kemampuan awal kedua sampel yang menjadi objek penelitian bersifat homogen atau tidak. Sehingga pada uji homogenitas digunakan data pre-test siswa. Uji homogenitas dapat dilakukan menggunakan rumus uji Fhitung. Berdasarkan hasil penelitian diperoleh seperti pada garfik berikut ini.

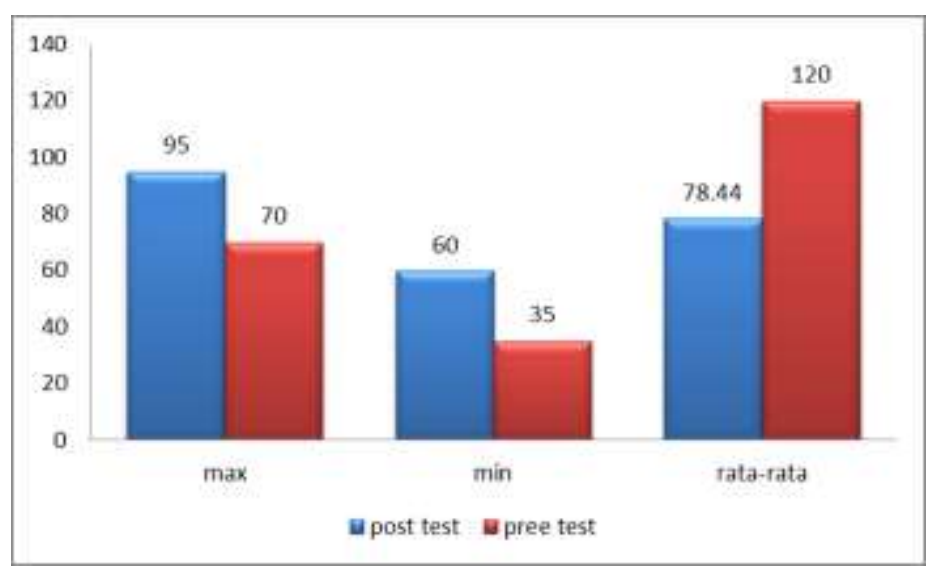

Grafik 1

Uji Homogenitas Pret test dan Post Tes

Berdasarkan hasil perhitungan untuk uji homogenitas sampel diperoleh x2hitung $=1$,40dan x2tabel $=2,40$ taraf signifikan $5 \%$ berdasarkan kriteria penguji jika x2hitung<x2tabel makan sampel homogen. Dengan demikian dapat dikatakan bahwa kedua sampel yaitu Pret test dan Post test memiliki kemampuan yang homogenitas .

c. Uji Hipotesis (uji-t)

Uji hipotesis dilakukan untuk mengetahui apakah ada perbedaan hasil belajar PPKn siswa sebelum menggunakan media pembelajaran Team Assisted individualization (TAI)dan setelah menggunakan model pembelajaran untuk membuktikan signifikan perbedaan model pembelajaran sebelum dan sesudah menggunakan media pembelajaran Team Assisted individualization (TAI) perlu diuji secara statistik dengan t-test paired/berpasangan.

Berdasarkan hasil analisis uji normalitas diperoleh bahwa pada pret test dan Post test tersebut terdistribusi normal. Selanjutnya dilakukan uji hipotesis untuk 
mengetahui apakah hipotesis yang diajukan diterima atau ditolak. Berdasarkan data hasil perhitungan uji homogenitas diperoleh bahwa Fhitung < Ftabelsehingga kedua sampel dikatakan homogen dan $n_{1}=n_{2}$, maka dalam pengujian hipotesis diuji menggunakan uji t-test dengan rumus paired/berpasangan.

Varian sampel 1 (S12)

$$
\begin{aligned}
\mathrm{S} 12= & \frac{\mathrm{N} \cdot \Sigma \mathrm{X}_{1}^{\mathrm{n}}-\left(2 \mathrm{LX}_{1}\right)^{\mathrm{2}}}{\mathrm{N}(\mathrm{N}-1)}=\frac{(16) \cdot(41.800)-(800)^{2}}{16(16-1)} \\
= & \frac{668.800-640.000}{16(15)}=\frac{28.800}{240}=120
\end{aligned}
$$

Varian sampel 2 (S22)

$$
\begin{aligned}
& \mathrm{S} 22=\frac{\mathrm{N} \cdot \mathrm{\Sigma \textrm {K } _ { 2 } ^ { 2 }}-\left(\mathrm{EX}_{2}\right)^{2}}{\mathrm{~N}(\mathrm{~N}-1)}=\frac{(16) \cdot(99.725)-(1.255)^{2}}{16(16-1)} \\
& =\frac{1.595 .600-1.575 .025}{16(15)}=\frac{20.575}{240}=85,73
\end{aligned}
$$

Simpangan baku sampel 1 (S1)

$$
\begin{aligned}
\mathrm{S} 1 & =\sqrt{\frac{\mathrm{N} \cdot \mathrm{LX}_{1}^{2}-\left(\mathrm{LX}_{1}\right)^{2}}{\mathrm{~N}(\mathrm{~N}-1)}}=\sqrt{\frac{(16) \cdot(41.800)-(800)^{2}}{16(16-1)}} \\
& =\sqrt{\frac{668.800-640.000}{16(15)}}=\sqrt{\frac{28.800}{240}}=\sqrt{120}
\end{aligned}
$$

$=10,95$

Simpangan baku sampel 2 (S2)

$\mathrm{S} 2=\sqrt{\frac{\mathrm{N} \cdot \mathrm{LX}_{2}^{2}-\left(\mathrm{LN}_{2}\right)^{2}}{\mathrm{~N}(\mathrm{~N}-1)}}=\sqrt{\frac{(16) \cdot(99.725)-(1.255)^{2}}{16(16-1)}}$

$$
=\sqrt{\frac{1.595 .600-1.575 .025}{240}}=\sqrt{\frac{20.575}{240}}=\sqrt{85,73}
$$

$\mathrm{S} 2=9,26$

Hitung nilai korelasi $r$

$\mathrm{r}$

$$
\begin{aligned}
& \frac{n \sum x y-\left(\sum x\right)\left(\sum y\right)}{\sqrt{n\left(\sum x^{2}\right)}-\left(\sum x\right)^{2} \sqrt{n \sum y^{2}-\left(\sum y\right)^{2}}}= \\
& \frac{16(62725-(800)(1255)}{\sqrt{16(41800)-(800)^{2}} \sqrt{16(99725)-\left(1255^{2}\right.}}
\end{aligned}
$$

\begin{tabular}{|c|c|c|c|c|c|c|}
\hline \multirow{3}{*}{4} & \multirow[b]{2}{*}{ Hasbiyallah } & \multirow[b]{2}{*}{55} & \multirow[b]{2}{*}{70} & \multicolumn{3}{|l|}{ O } \\
\hline & & & & 302 & 4900 & 3850 \\
\hline & & & & 5 & & \\
\hline \multirow[t]{2}{*}{5} & Heriawan & 35 & 75 & 122 & 5625 & 2625 \\
\hline & & & & 5 & & \\
\hline 6 & Hilwan & 60 & 80 & $\begin{array}{l}360 \\
o\end{array}$ & 6400 & 4800 \\
\hline \multirow[t]{2}{*}{7} & Hirman & 45 & 70 & 202 & 4900 & 3150 \\
\hline & Husnul & 50 & 85 & $\begin{array}{l}5 \\
250\end{array}$ & 7225 & 1950 \\
\hline 8 & Khatimah & & & 0 & $1=-5$ & - $1-50$ \\
\hline \multirow[t]{2}{*}{9} & Iqozul Human & 35 & 65 & 122 & 4225 & 2275 \\
\hline & & & & 5 & & \\
\hline \multirow[t]{2}{*}{10} & Liza Amelia & 45 & 75 & 202 & 5625 & 3375 \\
\hline & & & & 5 & & \\
\hline \multirow[t]{2}{*}{11} & Miftahul & 45 & 75 & 202 & 5625 & 3375 \\
\hline & Waruq & & & 5 & & \\
\hline \multirow[t]{2}{*}{12} & Nasarudin & 60 & 80 & 360 & 6400 & 4800 \\
\hline & & & & $\mathrm{O}$ & & \\
\hline \multirow[t]{2}{*}{13} & Rahmi & 55 & 85 & 302 & 7225 & 4675 \\
\hline & & & & 5 & & \\
\hline \multirow[t]{2}{*}{14} & Samsul Hadi & 70 & 90 & 490 & 8100 & 6300 \\
\hline & & & & $\mathrm{O}$ & & \\
\hline \multirow[t]{2}{*}{15} & Sudirja & 40 & 85 & 160 & 7225 & 3400 \\
\hline & & & & $\mathrm{O}$ & & \\
\hline \multirow[t]{2}{*}{16} & Susilawati & 45 & 80 & 202 & 6400 & 3600 \\
\hline & & & & 5 & & \\
\hline \multirow{2}{*}{\multicolumn{2}{|c|}{ Jumlah }} & 800 & 125 & 418 & 9972 & 62725 \\
\hline & & & 5 & OO & & \\
\hline \multirow{2}{*}{\multicolumn{2}{|c|}{ Rata-rata }} & 50 & 78,5 & 261 & 6232 , & 3920 , \\
\hline & & & & 2,5 & 8125 & 3125 \\
\hline \multicolumn{2}{|l|}{ S2 } & 10.95 & 9.25 & & & \\
\hline
\end{tabular}

$$
\begin{aligned}
& \frac{-400}{\sqrt{28800-\sqrt{20575}}}=\frac{-400}{24055749} \\
= & -0,002
\end{aligned}
$$

Hitungan dk

Mencari $F_{\text {tabel }}$

$\mathrm{dk}$ pembilang $=\mathrm{n}-1$

$$
=16-2=14
$$

$\mathrm{dk}$ penyebut $=\mathrm{n}-1$

$$
=16-2=14
$$

Tabel 4

Uji Hipotesis (Uji-t) Data pret test dan Post test

\begin{tabular}{|c|c|c|c|c|c|c|c|}
\hline No & Nama siswa & $\mathrm{X}$ & $\mathrm{Y}$ & $\mathrm{X} 2$ & & X.Y & -28.44 \\
\hline 1 & $\begin{array}{l}\text { Ahmad Yusuf } \\
\text { Az Zuhri }\end{array}$ & 40 & 95 & $\begin{array}{l}160 \\
0\end{array}$ & 9025 & 3800 & $(-0,025)$ \\
\hline 2 & Aswandi & 50 & 85 & $\begin{array}{l}250 \\
0\end{array}$ & 7225 & 4250 & $t=\frac{-28,44}{\sqrt{12,875}}=\frac{-28,44}{3,588}$ \\
\hline 3 & Dwi Nur Astuti & 70 & 60 & 490 & 3600 & 4200 & .926 \\
\hline
\end{tabular}<smiles>C1CCCC1</smiles>

$\bar{X}_{1: 50}$

$\bar{X}_{2: 78,44}$

$\mathrm{S}_{1: 120}^{2}$

$\mathrm{S}_{2}^{2}: 85,73 \mathrm{~S} 1=10,95$

$\mathrm{N} 1: 16$ S2 $=9,26$

N2 $: 16$

$\mathrm{r}:-0,002$

$t=\frac{\overline{\mathrm{X}}_{1}-\overline{\mathrm{X}}_{2}}{\sqrt{\frac{\mathrm{S}_{1}^{2}}{\mathrm{n}_{1}}}+\frac{\mathrm{S}_{2}^{2}}{\mathrm{n}_{2}}-2 \mathrm{r}\left(\frac{\mathrm{S}_{1}}{\sqrt{\mathrm{n}_{1}}}\right)\left(\frac{\mathrm{S}_{2}}{\sqrt{\mathrm{n}_{2}}}\right)}$

$t=\frac{50-78,44}{\sqrt{\frac{120}{16}+\frac{85,73}{16}-2\left(-0,002\left(\frac{10,95}{\sqrt{16}}\right)\left(\frac{9,26}{\sqrt{16}}\right.\right.}}$

$t=\frac{-28,44}{\sqrt{7,5+5,36-(-0,004)\left(\frac{10,95}{4}\right)\left(\frac{9,26}{4}\right)}}$

$t=\frac{-28,44}{\sqrt{12,86-(-0,004(2,738)(2,315)}}$ 
Dalam menentukan ttabelterlebih dahulu akan ditentukan derajat kebenarannya. Denganrumus: $\mathrm{dk}=$ $\mathrm{n}-2=16-2=14$. Dengan dk 14 dan taraf signifikan $(\alpha)$ 0,05 (5\%) maka t tabel $=1,761$. Dari hasil perhitungan secara statistik uji t-test diperoleh thitung sebesar 7,926. Oleh karena itu thitung $\geq$ ttabel $(7,926 \geq 1,761)$.

Dari data tersebut maka dapat disimpulkan bahwa terdapat pengaruh yang signifikan antara hasil belajar PPKn siswa kelas X MA Al-Intishor tahun pelajaran 2018/2019 setelah perlakuan media pembelajaran Team Assisted Individualization(TAI) diterapkan. Karena hasil belajar siswa setelah menggunakan media pembelajaran Team Assisted Individualization (TAI) $\geq$ ttabel.

\section{TEMUAN DAN DISKUSI}

Penelitian ini melibatkan siswa kelas X MA AlIntishor Mataram dengan jumlah seluruh 16 siswa menggunakan model pembelajaran Team Assisted Individualization (TAI) dengan memelakuan pretest dan postest. dari hasil pretes dan postest diperoleh nilai terendah untuk pretes 35 , nilai tertinggi 70 , dan ratarata 50 sedangkan postest diperoleh nilai terendah 60 , tertinggi 95 , dan rata-rata 78,44 .

Uji normalitas digunakan untuk mengetahui data berdistribusi normal atau tidak. Penentuan uji normalitas yaitu menggunakan data pretest dan postest menggunakan rumus Chi- kuadrat dengan kriteria pengujian jika Xhitung $\leq$ Xtabel maka berdistribusi normal, tetapi jika Xhitung $\geq$ Xtabel maka data berdistribusi tidak normal. Jadi dapat disimpulkan bahwa data pretest berdistribusi normal sebab Xhitung $=2,352<$ Xtabel $=11,070$ dengan taraf signifikan $5 \%$ dan posttest berdistribusi normal dengan hasil Xhitung $=1,247<$ Xtabel $=11,070$ dengan taraf signifikan $5 \%$.

Uji homogenitas dilakukan bertujuan untuk mengetahui apakah data pretest dan postes bersifat homogen atau tidak. Dari data tersebut diperoleh Fhitung $=1,40<$ Ftabel $=2,40$ maka dapat disimpulkan bahwa data bersifat homogen.

Untuk mengetahui model pembelajaran Team Assisted Individualization (TAI) berpengaruh terhadap hasil belajar siswa maka peneliti menggunakan uji $t$ sebagai uji hipotesis pada penelitian ini. Berdasarkan hasil perhitungan diketahui petest dengaan rata-rata 50 sedangkan postest dengan rata-rata 78,44. Dengan demikian uji $\mathrm{t}$ diperoleh thitung $=7,926$ sedangkan ttabel $=1,761$ dengan taraf signifikan 0,05. Karena thitung > ttabel maka Ho ditolak dan $\mathrm{Ha}$ diterima.Artinya terdapat pengaruh yang signifikan menggunakan model pembelajaran Team Assisted Individualization (TAI) berpengaruh terhadap hasil belajar pada mata pelajaran PPKn kelas X MA AlIntishor Mataram.
Hasil penelitian yang diterapkan dengan menggunakan model pembelajaran TAI pada pembelajaran di kelas bagaimana terlihat siswa lebih aktif dalam mengikuti pembelajaran PPKn, siswa lebih berkomunikatif dalam belajar kelompok, siswa dengan menunjukan menunjukan kerjasama yang baik dalam kelompok melalui dengan membantu teman yang berkemampuan lemah. Oleh sebab itu model pembelajaran TAI menciptakan suasana belajar siswa yang lebih menyenangkan.

Namun tidak semua siswa menunjukan hasil yang baik dengan menggunakan model pembelajaran ini, tetapi masih ada siswa yang memiliki nilai dibawah KKM dan ada pula siswa yang menunjukan hasil di atas KKM.Dikatakan tuntas apabila nilai mencapai >75. Beberapa siswa yang masih di bawah KKM disebabkan oleh siswa yang masih kurang tanggap terhadap materi yang disampaikan, ada siswa yang purapura paham namun sebenarnya tidak paham terhadap materi yang disampaikan.

Pengaruh hasil belajar PPKn menggunakan model pembelajaran TAI ini melalui pengkombinasian keunggulan kelompok dan pembelajaran individu.Dalam model ini diterapkan bimbingan antar siswaa yang pandai bertanggung jawab terhadap siswa yang lemah dan siswa dituntut untuk aktif mencari pengalaman baru dalam pembelajaran TAI. Dengan demikian, siswa yang pandai dapat mengembangkan kemampuan dan keterampilannya serta siswaa yang lemah dapat terbantu.

Hal ini sesuai dengan kelebihan dari model pembelajaran Team Assisted Individualization (TAI) yang dikemukakan oleh Slavin dalam [6] bahwa model pembelajaran TAI berpengaruh terhadap hasil belajar siswa. Hasil ini juga sejalan pada penelitian yang dilakukan oleh [19] mengungkapkan bahwa prestasi belajar PPKn siswa lebih baik menggunakan pembelajaran Team Assisted Individualization (TAI) dibanding dengan mengikuti pembelajaran konvensional.Penelitian ini senada juga dilakukan oleh [20] bahwa penerapan pembelajaran TAI dapat terhadap hasil belajar pada mata pelajaran PPKn kelas X MA AlIntishor Mataram.

\section{E. SIMPULAN DAN SARAN}

Berdasarkan hasil penelitian menunjukkan bahwa ada pengaruh yang signifikan pengajaran menggunakan media pembelajaran Team Assited Individualization (TAI) lebih meningkat hasil belajar PPKn siswa daripada siswa yang diajarkan menggunakan metode ceramah pada siswa kelas kelas X MA Al-Intishor Mataram tahun pelajaran 2018/2019, dengan nilai ratarata pada pretest sebelum 50 sebesar dan pada posttest sebesar 78,44, Berdasarkan hasil perhitungan uji hipotesis dengan menggunkan rumus uji t-paired, maka diperoleh ${ }^{t_{\text {hitung }} \text { sebesar }}$ 7,926 sedangkan nilai $t_{\text {tabel }}$ 
pada taraf signifikan $5 \%$ dengan diperoleh harga $t_{\text {tabel }}$ sebesar 1,761. Jadi dari hasil perhitungan dapat di simpulkan $t_{\text {hitung }} \geq t_{\text {tabel }}$ yang berarti hipotesis (Ha) diterima dan hipotesis alternatif (Ho) ditolak, sehingga penelitian ini dapat disimpulkan bahwa ada pengaruh Model Pembelajaran Team Assited Individualization (TAI) dapat mempengaruhi hasil belajar siswa pada PPKn kelas X MA Al-Intishor Mataram tahun pelajaran 2018/2019.

Saran yang dapat disampaikan berdasarkan penelitian yang telah dilakukan yaitu bagi guru, disarankan untuk menerapkan media pembelajaran Team Assited Individualization (TAI) dalam mengelola pembelajaran untuk dapat meningkatkan hasil belajar siswa di MA Al-Intishor Mataram. Bagi calon peneliti, yang berminat untuk melakukan penelitian lebih lanjut tentang model pembelajaran Team Assited Individualization (TAI) untuk mata pelajaran PPKn maupun bidang ilmu lainnya yang sesuai, agar memperhatikan kekurangan-kekurangan dalam penelitian ini sebagai bahan pertimbangan untuk perbaikan dan penyempurnaan penelitian yang akan dilaksanakan.

\section{UCAPAN TERIMA KASIH}

Penulis mengucapkan terima kasih kepada semua pihak yang senantiasa memberikan dukungan dana maupun data dan saran masukan kepada penulis sehingga artikel ilimiah ini selesai dengan baik.

\section{DAFTAR RUJUKAN}

[1] P. Ngalim, "Evaluasi Hasil Belajar," Yogyakarta: Pustaka Pelajar, 2014.

[2] R. Indonesia, "Undang-undang Republik Indonesia Nomor 20 tahun 2003 tentang Sistem Pendidikan Nasional," Jakarta Pemerintah Republik Indones., 2003.

[3] R. Indonesia, "Undang-undang Republik Indonesia nomor 14 tahun 2005 tentang Guru dan Dosen," Sekr. Negara. Jakarta, 2005.

[4] Anjani, "Pengaruh Model Pembelajaran Inside-OutsideCircle Terhadap Hasil Belajar Siswa Mata Pelajaran PPKn SMP Negeri 7 Mataram Tahun 2015/2016,” Progr. Stud. Pendidik. Pancasila dan Kewarganegaraan. Univ. Muhammadiyah Mataram Mataram., 2015.

[5] E. Mulyasa, Pengembangan dan Implementasi Kurikulum 2013. PT Remaja Rosdakarya, 2013.

[6] H. Miftahul, "Model-model Pengajaran dan Pembelajaran,” Yogyakara: Pustaka Pelajar, 2013.

[7] Sugiyono, Metode Penelitian Pendidikan R \& D. Bandung: Alfabeta, 2017.

[8] K. Sundara, Metode Penelitian Pendidikan (Teori dan Aplikasi). Mataram: UM-Mataram, 2012.

[9] Sugiyono, "Metode Penelitian kuantitatif kualitatif dan R dan D," Alf. Bandung, 2010.

[10] N. Sudjana, "Penelitian Hasil Belajar Mengajar," Bandung: Rosdakarya, 2005.

[11] H. Mahmud, "Metode Penelitian Pendidikan," Bandung CV Pustaka Setia, 2011.

[12] Sudaryono, Metode Penelitian Pendidikan. Jakarta: Prenadamedia Group, 2016.

[13] B. Sudjarwo, "Manajemen Penelitian Sosial," Bandung
Mandar Maju, 2009.

[14] C. N. D. A. Ahmadi, "Metodologi Penelitian, cet," Ke-10 (Jakarta Bumi Aksara, 2009), vol. 85, 2009.

[15] M. P. Ahmad Susanto, Teori Belajar dan Pembelajaran di Sekolah Dasar. Kencana, 2016.

[16] M. N. Purwanto, Prinsip-prinsip dan Teknik Evaluasi Pengajaran. Remaja Rosdakarya, 2000.

[17] A. Suharsimi, "Dasar-dasar Evaluasi Pendidikan Edisi 2," Jakarta PT Bumi Aksara, 2013.

[18] B. Burhan, "Metodologi Penelitian Kuantitatif," Jakarta Kencana Prenada Media Gr., 2005.

[19] M. S. Hadinata and I. M. Syahruddin, "Pengaruh Model Pembelajaran Team Assisted Individualization (TAI) Terhadap Prestasi Belajar IPS kelas IV SD Gugus 4 Bondalem Kecamatan Tejakula,” Mimb. PGSD Undiksha, vol. 1, no. 1, 2013.

[20] I. Liliani, "Penerapan Model Pembelajaran Kooperatif Tipe Team Assisted Individualization (TAI) Untuk Meningkatkan Hasil Belajar Matematika Siswa Kelas VC SD Negeri 161 Pekanbaru." 